\section{THE PITFALLS OF THE NUMISMATIC EVIDENCE. THE AUXILIARY FORT OF ARCOBADARA (ILIŞUA, BISTRIŢA-NĂSĂUD COUNTY, ROMANIA) ${ }^{1}$}

\begin{abstract}
In the light of the publication of the numismatic monograph from the site of Arcobadara (Ilişua) in Roman Dacia (Romania), the present work is pointing out the pitfalls that the scholar may have to face when dealing with old and non-professional publication of artefacts.

Keywords: numismatic evidence, Arcobadara (Ilişua), state of research and publication, genuine and plated silver coinage, general pattern
\end{abstract}

\section{Cristian Găzdac}

Institute of Archaeology and Art History Cluj-Napoca cgazdac2000@yahoo.co.uk

\section{Corneliu Gaiu}

Museum of Bistrița corneliugaiu@yahoo.fr

\section{Ágnes Alföldy-Găzdac}

National History Museum of Transylvania Cluj-Napoca

alfoldyagnes@yahoo.com

DOI: $10.14795 /$ j.v2i3.125

SSN $2360-266 \mathrm{X}$

ISSN-L 2360 - 266X
$\mathbf{T}$ here were always debates on how we should regard the quantity of artefacts as a relevant evidence for archaeological, historical, numismatic or economic interpretations.

The recent publication of the numismatic monograph of the Roman site Arcobadara (Ilişua), ${ }^{2}$ (maps 1-4) has offered us the possibility to point out the pitfalls that the numismatic evidence in combination with the state of research and publication may provide.

Based on a catalogue of coins found during the archaeological excavations of 1978-1995 on the territory of the auxiliary fort ${ }^{3}$ a first comparative graph of genuine and plated silver coins was made.

At an overall view, this graph indicates a general pattern known not only for Dacia but also for many other areas of the Roman Empire following a general pattern regarding the imperial monetary policy at the beginning of the $3^{\text {rd }}$ century AD. ${ }^{4}$

On this graph some 'anomalies' from a general pattern may be noticed: a strong predominance of plated coins bearing the portrait of Trajan; and the dominance of 'good' silver coins for the periods of AD 238-244 and AD 244249.

While working on the numismatic monograph of the site we came across the list of coins from the same site published by Torma K. in 1865. ${ }^{5}$ The author mentions that the coins were found on the territory of the fort

\footnotetext{
This work was made available owing to the financial support offered by research projects UEFISCSDI PN-II-ID-PCE-2012-4-0210 and PN-II-RU-TE 20123-0216.

2 GĂZDAC/GAIU 2011.

3 PROTASE/GAIU/MARINESCU 1997

${ }^{4}$ GĂZDAC 2009, 1487-1498; GĂZDAC 2010, 98-100, 149-151, 177-178.

5 TORMA 1865, 31-34.
} 


\section{Studies}

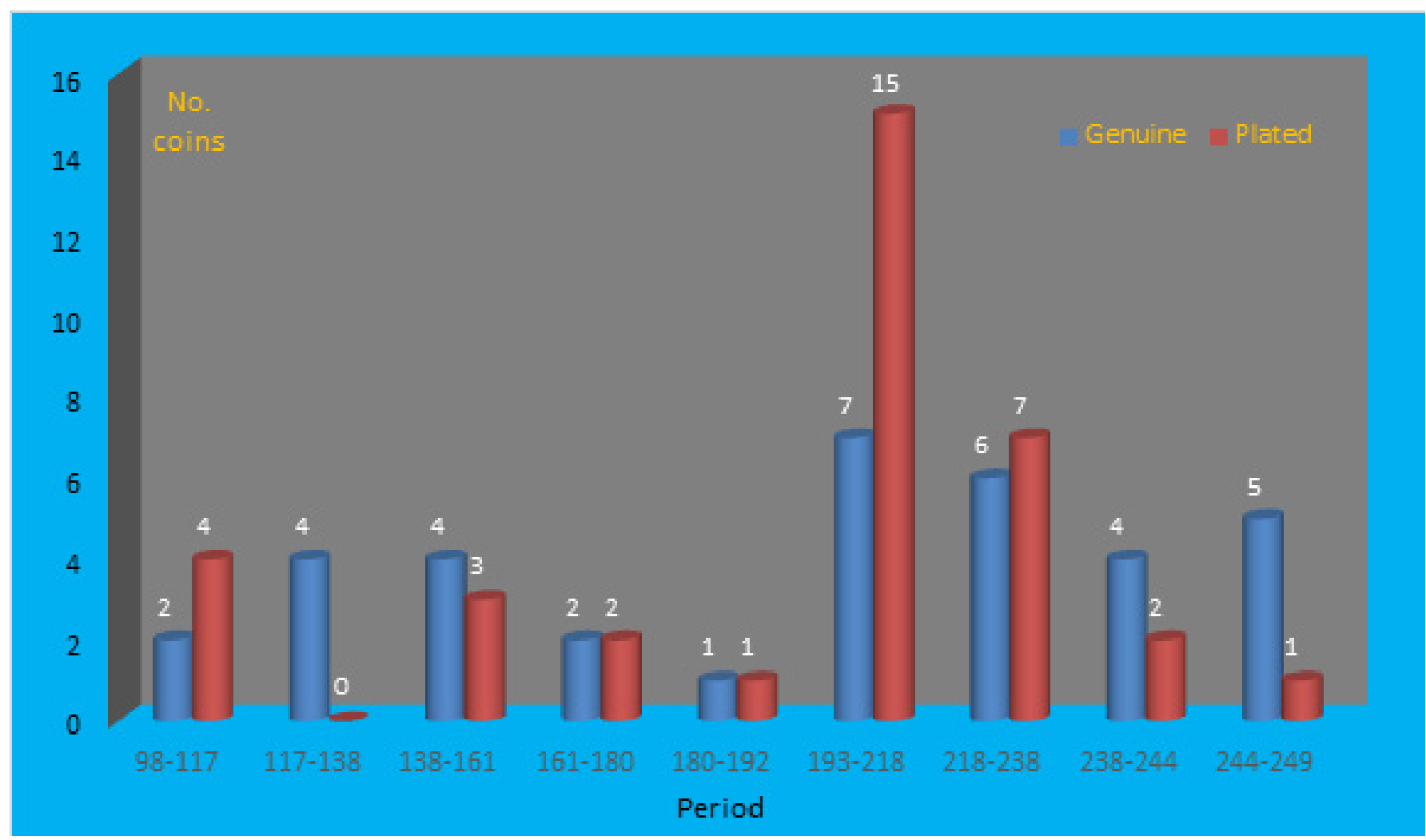

Fig. 1. Graph of the silver coin finds from Arcobadara (Ilişua) - cavalry fort (after GĂZDAC 2009) (๔ Cristian Găzdac).

and surroundings (map 3). ${ }^{6}$ Thus, after updating the coin identification by Torma based on Cohen work, first edition ${ }^{7}$ according to the Roman Imperial Coinage, one could arrive to the following comparative graph of genuine and plated silver coins found at the auxiliary fort of Arcobadara:

At this stage of research, we would definitely face a very strong 'anomaly' from the general pattern: a huge presence of genuine/'good' silver coins.

The explanation comes purely from the state of research and publication at that time. Firstly, the author, Torma K. was not a numismatist but a passionate of archaeology; in those times, there were not many aware

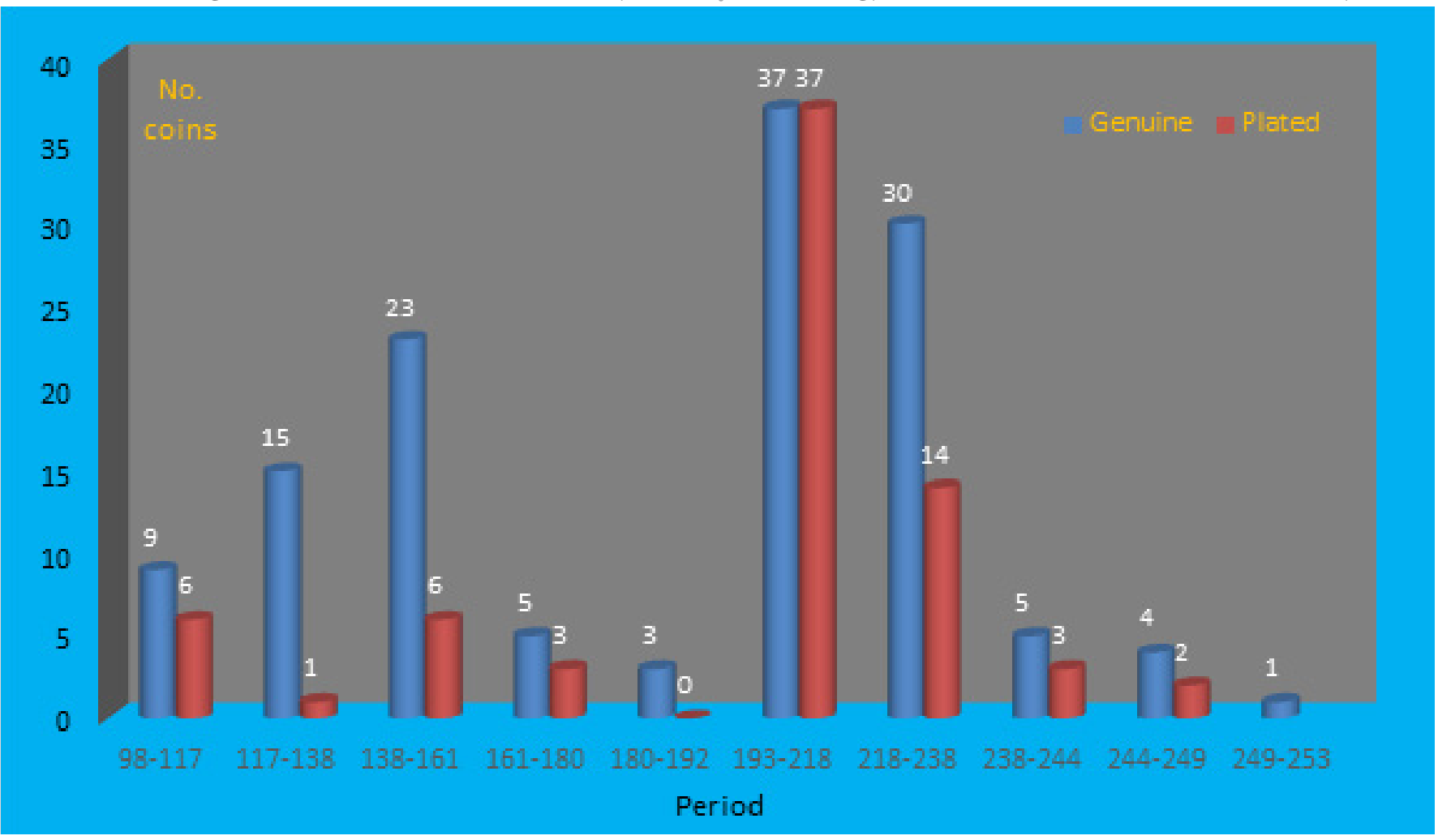

Fig. 2. Graph of the silver coin finds from Arcobadara (Ilişua) - cavalry foṛt, including the coins on the Torma's list. (@ Cristian Găzdac)

6 TORMA 1865, 31.

7 COHEN 1854 . 


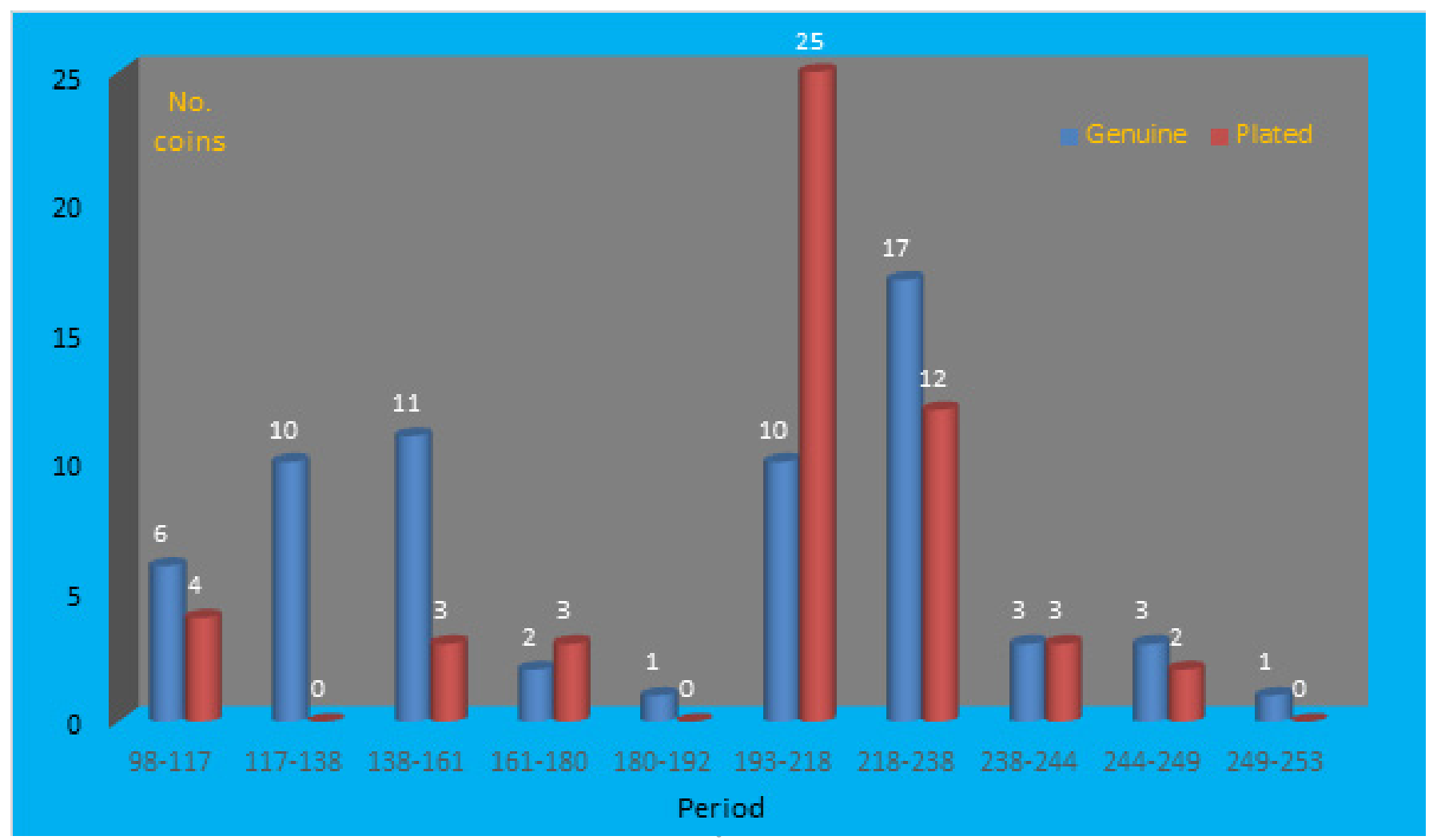

Fig. 3. Graph of the silver coin finds from Arcobadara (Ilişua) - cavalry for̆t, the present state of research.(৫ Cristian Găzdac)

of identifying and mentioning as so of the plated coins. Therefore, in many cases the author could have just taken a plated coin for a genuine one.

In the same process of gathering all numismatic evidence from the site of Arcobadara we have re-analysed all the numismatic material (the excavations of 1978-1995); the new coin finds (the excavations of 1996-2006; the field survey of 2007). At the same time, we went through the entire work of Torma K., an enterprise that have revealed that some of the coins found by him were in fact discovered in the 'western necropolis' (belonging to the civilian settlement) and in the baths. ${ }^{8}$

Therefore, although, the majority of the coins found by Torma K., most likely, come from the auxiliary fort territory, still, we do not know which ones and how many of them.

Thus, in a third comparative graph, we introduced the most recent data we hold, at the moment, on the genuine and plated silver coins - comprised in the numismatic monograph of the site of Arcobadara ${ }^{9}$ - seen and studied by us. We removed the coins found by Torma, as there was no certain evidence on the findspot and the real proportion of genuine and plated pieces.

It can be easily noticed that the above mentioned 'anomalies' have vanished and the spectrum of genuine and plated coins went back to 'normal' following a general pattern of a monetary policy.

This methodological study is not an isolated case for Dacia. A similar one - with same impact - has been already demonstrated for the auxiliary fort of Gherla (37 km SW of Arcobadara-Ilişua, map 2). ${ }^{10}$

\footnotetext{
8 TORMA 1865, 14, 30; GĂZDAC/GAIU 2011, 16.

9 GĂZDAC/GAIU 2011.

10 GĂZDAC/ZĂGREANU 2007, 175-178
}

Thus, it becomes an important aim to see and study the old publications and, thus, maybe, we will get closer, by few steps, to the real historical picture.

\section{REFERENCES}

\section{COHEN 1854}

COHEN, H., Description générale de monnaies de la République romaine, Paris, 1854.

\section{GĂZDAC 2009}

GĂZDAC, C., The distribution of silver counterfeited coins in the forts from Roman Dacia. Fraud or monetary policy? In: Morillo, Á./Hanel, N./Martín, E. (eds.): Limes XX. XXth International Congress of Roman Frontier Studies, León (España), Septiembre, 2006 [Gladius 13, vol. 1], Léon, 14871498.

\section{GĂZDAC 2010}

GĂZDAC, C., Monetary circulation in Dacia and the provinces from the Middle and Lower Danube from Trajan to Constantine I (AD 106-337), $2^{\text {nd }}$ edition (Cluj-Napoca: Mega)

GĂZDAC/GAIU 2011

GĂZDAC, C./GAIU, C., Arcobadara (Ilişua) [Coins from Roman Sites and Collections of Roman Coins from Romania 6] (Cluj-Napoca: Mega).

GĂZDAC/ZĂGREANU 2007

GĂZDAC, C./ZĂGREANU, R., Reinterpreting numismatic evidence. A case study: the auxiliary fort from Gherla, Revista Bistriţei 21/1, 175-178.

PROTASE/GAIU/MARINESCU 1997

PROTASE, D./GAIU, C./MARINESCU, Gh., Castrul roman de la Ilişua (Bistriţa).

\section{TORMA 1865}

TORMA, K., Az Alsó-Ilosvai romai állótábor és müemlékei, Erdélyi Múzeum Emlékkönyve 3, 10-67. 


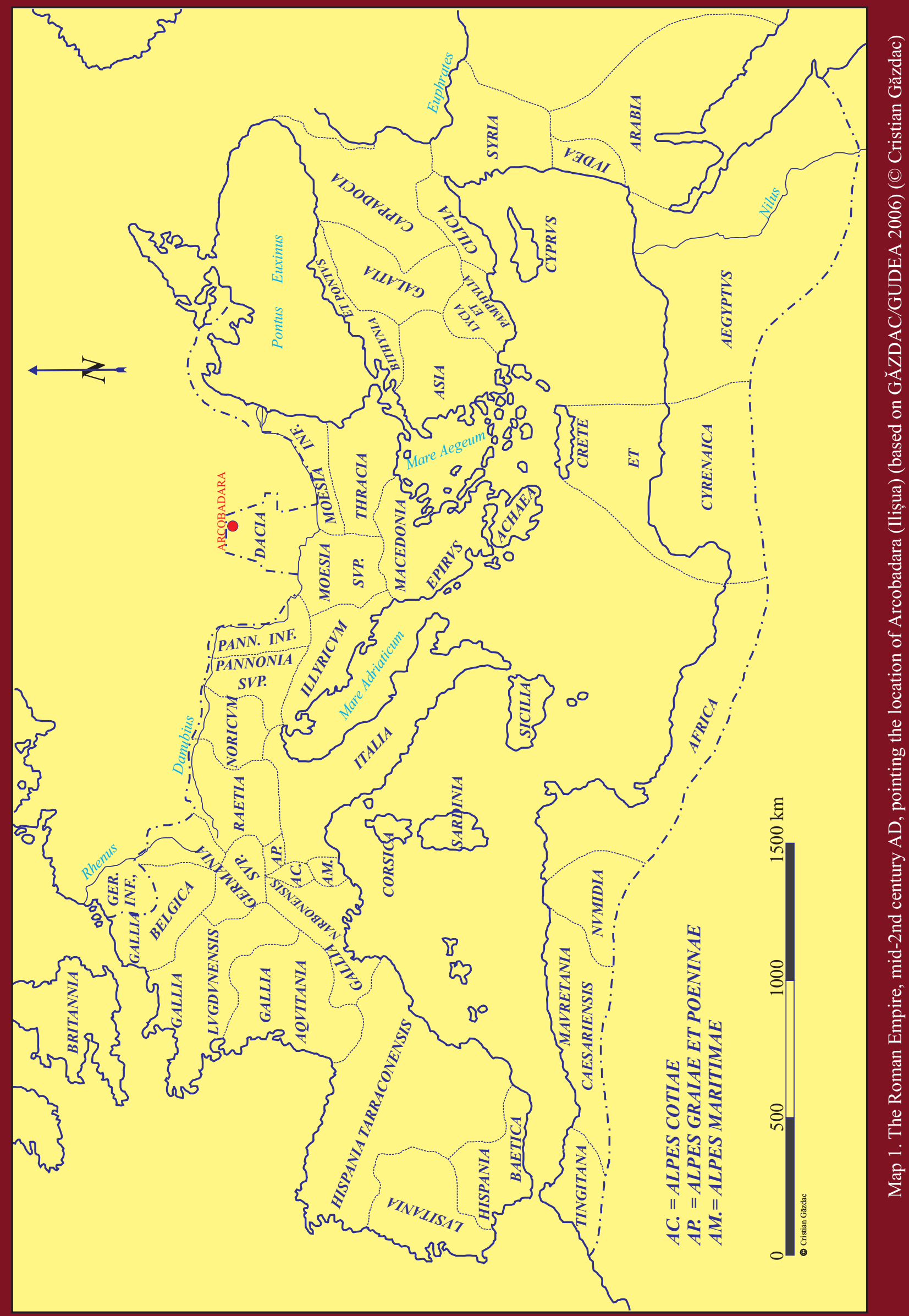




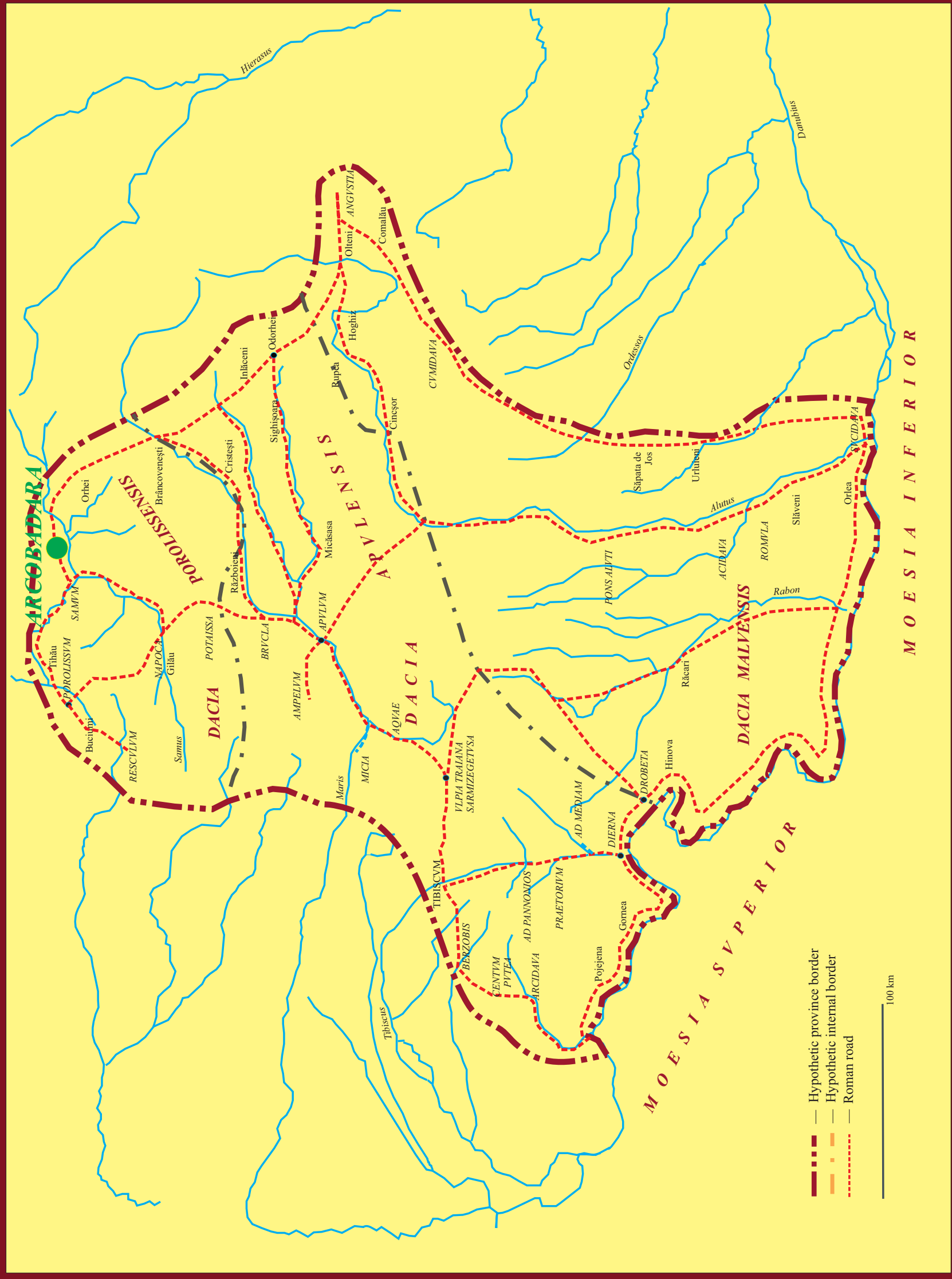

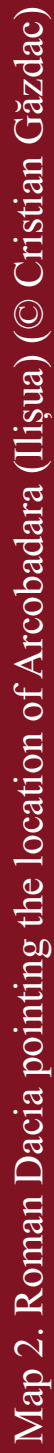




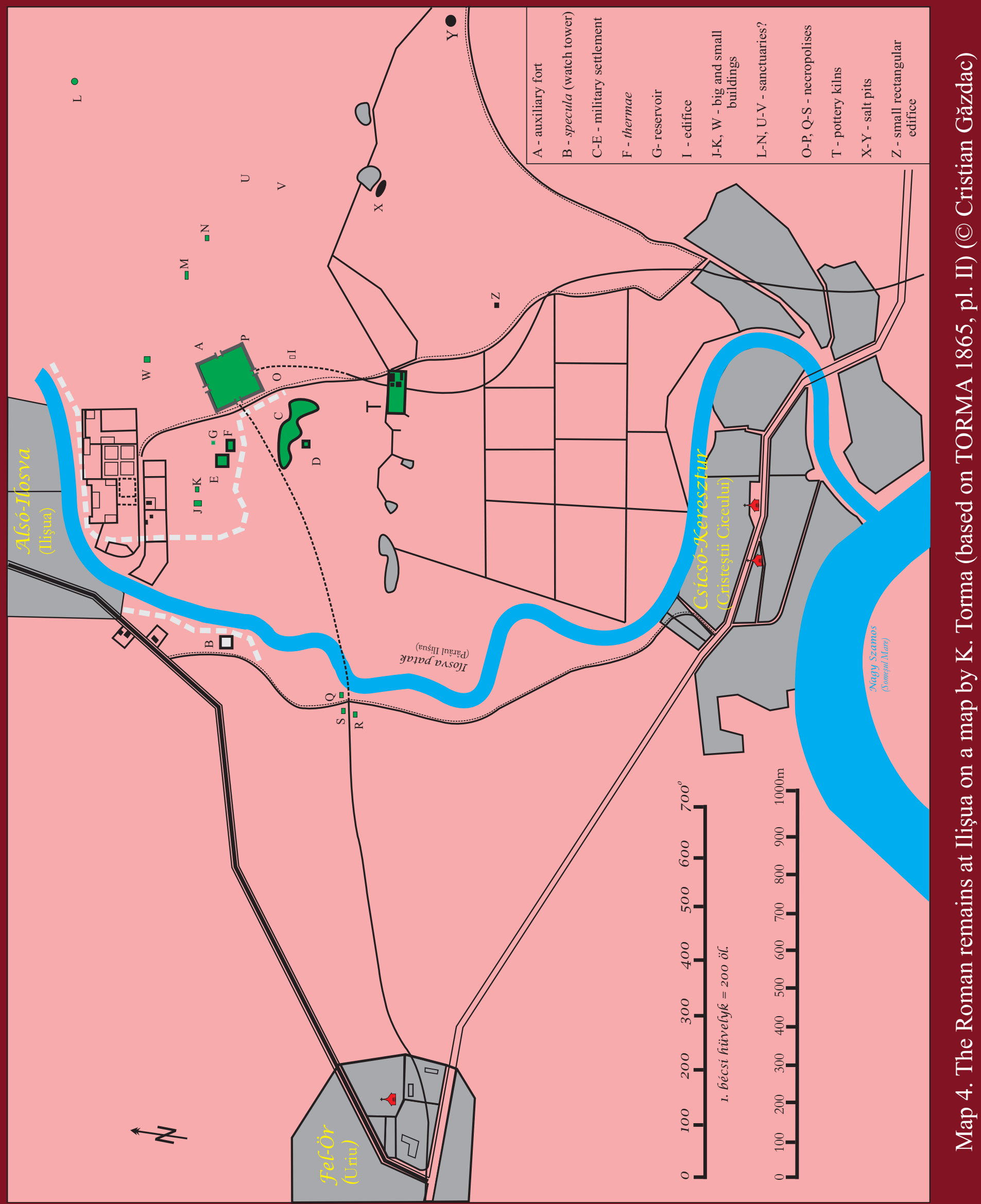




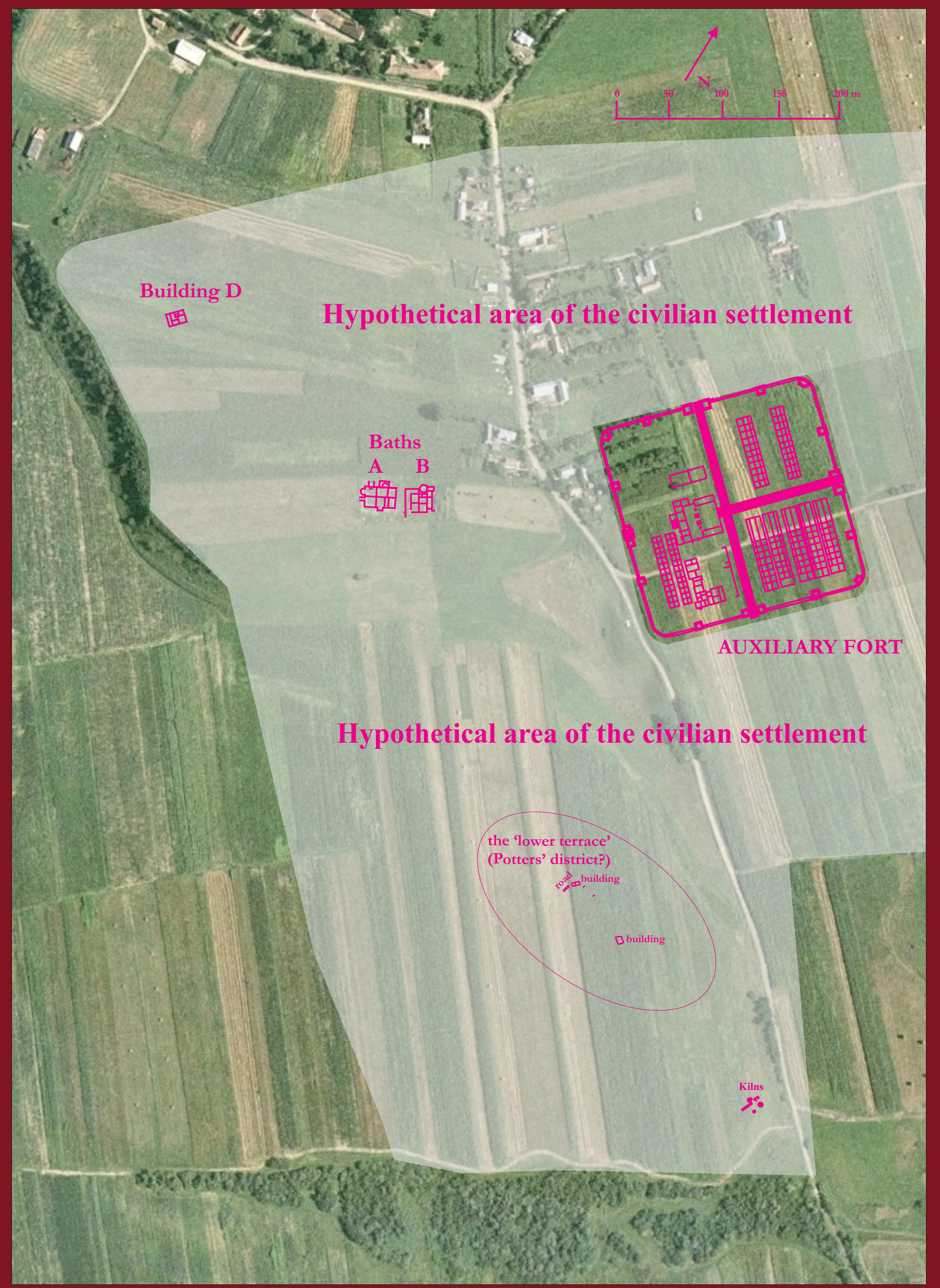

